\title{
GAMBARAN INFEKSI KECACINGAN PADA SISWA SDN 1-4 DESA MUARA LAUNG KABUPATEN MURUNG RAYA PROVINSI KALIMANTAN TENGAH TAHUN 2017
}

\author{
Nurhalina $^{1}$, Desyana ${ }^{2}$ \\ Program Studi Analis Kesehatan Universitas Muhammadiyah Palangkaraya \\ Email : nurhalina@umpalangkaraya.ac.id/ Hp : 081314536125
}

\begin{abstract}
ABSTRAK
Anak usia sekolah merupakan kelompok berisiko kecacingan karena perilaku hidup bersih dan sehat yang masih tergantung pada orang tua dan lingkungan sekitar. Kecacingan pada anak dapat menurunkan prestasi belajar akibat defisiensi gizi dan anemia. Pada Tahun 2012, World Health Organization (WHO) menyebutkan lebih dari 1,5 miliar orang atau $24 \%$ dari populasi dunia terinfeksi kecacingan dimana $60 \%$ diantaranya adalah anakanak. Di Indonesia prevalensi kecacingan mencapai angka di atas $20 \%$ dengan prevalensi tertinggi adalah $76,67 \%$ pada Tahun 2012. Sedangkan di Kalimantan Tengah prevalensi kecacingan mencapai $5.56 \%$ yang tersebar merata di seluruh Kabupaten/Kota. Penelitian ini bertujuan mengetahui gambaran infeksi kecacingan pada siswa SDN 1-4 Desa Muara Laung Kabupaten Murung Raya Tahun 2017.

Penelitian ini menggunakan metode observational study dengan pendekatan deskriptif. Populasi penelitian adalah semua siswa yang terdaftar di SDN 1-4 Desa Muara Laung, sedangkan sampel adalah siswa kelas I sampai kelas VI yang aktif pada pada Tahun Ajaran 2016/2017. Teknik penarikan sampel menggunakan metode cluster sampling dimana semua siswa dipilih secara acak berdasarkan kelas masing-masing. Metode pengumpulan data meliputi observasi, wawancara serta pemeriksaan feses langsung (natif) dengan menggunakan larutan $\mathrm{NaCl} 0.9 \%$ dan data dianalisis secara univariat.

Hasil penelitian menunjukkan bahwa tidak ada siswa SDN 1-4 Desa Muara Laung yang terinfeksi kecacingan yang ditandai dengan tidak ditemukannya telur dan atau larva serta cacing dewasa dalam specimen tinja yang diperiksa $(0.0$ $\%)$.
\end{abstract}

Kata Kunci : Kecacingan,

\section{PENDAHULUAN}

Kecacingan merupakan masalah

kesehatan masyarakat yang masih

tersebar luas di seluruh dunia terutama di negara-negara berkembang dengan

PHBS dan sanitasi yang buruk. Pada Tahun 2015, World Health Organization (WHO) melaporkan lebih dari $24 \%$ populasi dunia terinfeksi kecacingan dan $60 \%$ diantaranya adalah anak-anak. Penyebaran penyakit ini adalah
Pemeriksaan Feses Langsung

terkontaminasinya tanah dengan tinja yang mengandung telur dan atau larva cacing. Infeksi dapat terjadi bila telur infektif atau larva masuk ke dalam tubuh melalui mulut bersama makanan dan minuman yang terkontaminasi telur cacing atau tercemar tangan yang kotor.

Manusia merupakan hospes definitive sebagian besar spesies cacing yang kerapkali ditemukan dalam specimen tinja pasien terinfeksi. Di Indonesia penyebab utama infeksi kecacingan 
adalah spesies Ascaris lumbricoides, Trichuris trichiura dan cacing tambang yang masing-masing menyebabkan infeksi kecacingan dengan frekuensi 60-90\% terutama pada anak usia sekolah. enelitian Bisara dan Mardiana (2010) di Kecamatan Mantewe Provinsi Kalimantan Selatan ditemukan infeksi kecacingan pada anak usia sekolah sebesar $38.9 \%$ diantaranya $11.1 \%$ terinfeksi Ascaris lumbricoides, terinfeksi Trichuris trichiura (16.7\%), 1 kasus terifeksi Hymenolopsis nana dan $27.8 \%$ anak yang terinfeksi oleh 2 (dua) jenis cacing sekaligus yaitu Ascaris lumbricoides dan Cacing tambang. Pada umumnya orang tua sudah mengetahui tentang kecacingan, tetapi tidak dianggap berbahaya oleh orang tua sehingga upaya pencegahan belum sepenuhnya dilakukan.

Sejalan dengan penelitian Martila, Samuel Sandi dan Nopita Paembonan (2015) menunjukan tingginya prevalensi kecacingan pada anak usia sekolah. Hasil penelitian ditemukan $50 \%$ anak terinfeksi kecacingan di SDN Abe Jayapura, dimana infeksi terbanyak disebabkan oleh Ascaris lumbricoides (48.5\%), Trichuris trichiura (28.6\%), Cacing tambang ( 14.3 $\%)$ dan infeksi campuran yang disebabkan oleh 2 (dua) atau lebih jenis cacing yaitu $28.6 \%$. Meskipun frekuensi infeksi kecacingan menunjukan angka yang sigifikan, namun hasil uji statistik menunjukan tidak ada hubungan antara hygiene perorangan dengan kejadian infeksi kecacingan pada murid SD Abe
Jayapura. Peneliti menduga bahwa tingginya infeksi kecacingan pada populasi dimungkinkan karena faktor lain seperti status gizi, sanitasi lingkungan, tingkat imunitas dan lain-lain yang perlu diteliti lebih lanjut.

Menurut WHO (2011) faktor risiko yang berhubungan dengan infeksi kecacingan antara lain umur, jenis kelamin, immunitas, PHBS, sumber air bersih, pembuangan tinja serta faktor lingkungan fisik seperti kelembapan tanah, adanya lahan pertanian/ perkebunan, faktor sosial, ekonomi (meliputi pekerjaan, pendidikan dan penghasilan). Kelembapan tinggi memungkinkan pertumbuhan telur atau larva cacing menjadi stadium infektif terutama kelompok Soil Transmitted Helminths (STH), yaitu Ascaris lumbricoides, Necator americanus, Ancylostoma duodenale, Trichuris trichiura, Strongyloides stecoralis, dan beberapa spesies Trichostrongylus. Nematoda usus lainnya yang penting bagi manusia adalah Oxyuris vermicularis dan Trichinella spiralis (Safar, 2010).

Hasil survey kecacingan di Provinsi Kalimantan Tengah mencapai $5.56 \%$ dan $65 \%$ diantaranya pada anak usia sekolah terutama anak SD. Beberapa penelitian menunjukan kecacingan lebih banyak menyerang anak-anak terutama kelompok anak usia sekolah karena aktifitas bermain mereka banyak yang berhubungan dengan tanah dan Perilaku Hidup Bersih dan Sehat 
(PHBS) yang diterapkan keluarga kepada anak-anak. Berdasarkan laporan Dinas Kesehatan Provinsi Kalimantan Tengah hingga Tahun 2014 terdapat 51, 1 \% rumah tangga di Kalimantan Tengah yang telah menerapkan PHBS, angka tersebut meningkat dibandingkan dengan data pada tahun 2013 yang hanya berkisar $45.7 \%$.

Kementerian Kesehatan RI (2016) melaporkan bahwa pada aspek sumber air minum hanya $63.72 \%$ Rumah Tangga di Kalimantan Tengah yang memiliki sumber air minum bersih dan $31.90 \%$ Rumah Tangga yang memiliki sumber air minum layak. Sedangkan pada aspek pembuangan akhir tinja, terdapat $52.02 \%$ rumah tangga yang menggunakan septik tank, menggunakan sungai/ kolam (27.02 \%) dan $28.08 \%$ Rumah Tangga yang membuang tinja di lubang tanah/galian. Hal ini menunjukan bahwa keluarga dan atau anak-anak yang berisiko tinggi tertular infeksi kecacingan masih relative tinggi. Oleh karena itu penularan kecacingan pada anak-anak perlu dipelajari secara terus menerus untuk dapat menentukan cara pencegahan yang efektif.

Desa Muara Laung merupakan salah satu desa di Kabupaten Murung Raya, dimana mayoritas penduduk bermukim di pinggir Sungai Barito. Berdasarkan hasil observasi, kondisi sanitasi lingkungan warga sekitar belum memenuhi syarat kesehatan karena minimnya kepimilikan jamban serta kamar mandi, sehingga aktivitas mandi, Buang Air Besar (BAB) dan Buang Air Kecil (BAK) sebagian besar masih dilakukan di sungai. Begitupula dengan Sumber Air Bersih, mayoritas warga masih menggunakan air sungai untuk keperluan sehari-hari seperti mencuci piring, mencuci sayur mayur/ beras dan lain-lain. Hasil observasi juga menunjukan bahwa PHBS anak usia sekolah masih rendah seperti kebersihan kuku, kebersihan pakaian serta penggunaan alas kaki yang jarang ketika bermain di lingkungan sekolah terutama di SDN 1-4 Desa Muara Laung.

Penelitian ini bertujuan untuk mengetahui gambaran infeksi kecacingan pada siswa SDN 1-4 Desa Muara Laung Kabupaten Murung Raya dengan menggunakan metode feses langsung. Keuntungan dan kelebihan pemeriksaan feses langsung yaitu bahan dan reagennya mudah didapatkan, tidak banyak menggunakan alat, lebih mudah dikerjakan, kemungkinan kesalahan tekniknya kecil dan tidak mudah kering atau terkontaminasi dengan lingkungan sekitar dan hasil cukup akurat (Garcia, 1996).

\section{TINJAUAN PUSTAKA}

Kecacingan adalah penyakit infeksi yang disebabkan oleh parasite cacing golongan nematode usus khususnya media penularan melalui tanah, atau yang disebut sebagai Soil Transmitted Helmints (STH) diantaranya 
adalah Ascaris lumbricoides, Trichuris trichiura, cacing tambang (Necator americanus, Ancylostoma duodenale) dan strongloydes stercoralis. Kelompok ini merupakan golongan nematoda usus (Sudarto,2011)

Nematoda adalah cacing yang tidak bersegmen, bilateral simetris, mempunyai saluran cerna yang berfungsi penuh, biasanya berentuk silindris dan panjangnya bervariasi dari beberapa millimeter hingga lebih dari 1 meter. Nematoda usus biasanya matang dalam usus halus, dimana sebagian besar cacing dewasa melekat dengan kait oral atau lempeng pemotong. Cacing ini menyebabkan penyakit karena dapat menyebabkan kehilangan darah akibat perforasi cacing pada dinding usus, anemia dan alergi. Penyebaran invasi larva cacing menyebabkan bakteri sekunder.

\section{METODE}

Penelitian ini menggunakan metode observational study dengan pendekatan deskriptif yang bertujuan untuk menggambarkan kejadian infeksi kecacingan pada siswa di SDN 1-4 Kabupaten Murung Raya. Populasi adalah seluruh siswa kelas 1 (satu) sampai kelas 6 (enam), sedangkan sampel adalah siswa yang aktif pada tahun ajaran berjalan. Teknik penarikan sampel menggunakan metode cluster sampling, dimana sampel terdistribusi pada setiap kelas yang dipilih secara acak. Pertimbangan peneliti menggunakan teknik ini karena infeksi kecacingan dapat menyerang semua kelompok umur anak terutama anak-anak yang tinggal dengan kondisi sanitasi dan PHBS yang tidak memenuhi syarat kesehatan.

Pengumpulan data dilakukan dengan metode : (1) Observasi, untuk mengetahui kondisi sanitasi lingkungan serta PHBS responden (2) Wawancara untuk mengetahui PHBS (kebiasaan mencuci tangan, kebiasaan menggunakan alas kaki); (3) Dokumentasi, untuk mengetahui umur responden dan tingkat pendidikan orang tua; (4) Pemeriksaan feses langsung (metode natif) dengan menggunakan $\mathrm{NaCl} 0.9 \%$ lalu diamati dengan menggunakan mikroskop untuk mengidentifikasi telur dan atau larva serta cacing dewasa pada specimen tinja.

\section{PROSEDUR KERJA}

\section{Persiapan Sampel}

Responden dikumpulkan dalam 1 kelas dan diberikan tempat penampungan tinja yang telah diberikan label. Pada waktu bersamaan, peneliti juga melakukan penilaian dan wawancara kepada responden terkait PHBS yang meliputi kebiasaan mencuci tangan sebelum dan sesudah makan, mencuci tangan setelah bermain, kebiasaan menggunakan alas kaki, kebersihan kuku dan kebersihan pakaian. Sedangkan usia responden dan tingkat 
pendidikan orang tua, peneliti menggunakan data sekunder dari sekolah.

Dalam waktu yang sama, peneliti juga memberikan edukasi tentang tata cara penampungan specimen tinja dalam pot serta standarisasi sampel. Peneliti juga menitipkan surat kepada siswa terpilih berisi permohonan ijin survey kepada orang tua dan petunjuk pengumpulan specimen tinja dalam pot yang diberikan. Tinja yang diambil adalah tinja yang dikeluarkan pada pagi hari setelah bangun tidur, tidak tercampur air atau urin, dan siswa tidak dianjurkan untuk minum obat cacing pada malam harinya.

\section{Pemeriksaan Laboratorium, Teknik}

\section{Pemeriksan Feses Langsung}

a. Reagensia dan Bahan

1) Feses

2) Larutan $\mathrm{NaCl}$ fisiologis $0,9 \%$

b. Cara pemeriksaan sampel

1) Meneteskan 1-2 tetes larutan $\mathrm{NaCl}$ fisiologis 0,9\% pada kaca objek yang bersih.

2) Tinja diambil seujung lidi $( \pm 2$ mg) dengan menggunakan lidi, kemudian diaduk hingga rata pada larutan $\mathrm{NaCl}$ fisiologis 0,9\% lalu ditutup dengan cover slip.

3) Specimen diamati dibawah mikroskop mula-mula pembesaran 10x objektif dan kemudian dilanjutkan dengan lensa objektif 40x objektif

c. Interprestasi hasil

Positif : Jika ditemukan telur dan atau larva atau cacing dewasa dalam specimen tinja.

Negatif : Jika tidak ditemukan telur dan atau larva atau cacing dewasa dalam specimen tinja.

\section{HASIL}

Berdasarkan hasil wawancara, terdapat responden berusia $\leq 6$ tahun (33.3 \%), 6-10 tahun (39.4\%) dan > 10 tahun $(27.3 \%)$, dimana mayoritas berjenis kelamin laki-laki (55 \%). Pada aspek pendidikan orang tua, terdapat $9.1 \%$ responden dengan pendidikan orang tua SD dan paling banyak SMA (37.9\%).

Pada aspek PHBS, berdasarkan kebiasaan mencuci tangan terdapat 33.3 $\%$ responden yang "jarang" mencuci tangan dan $40.9 \%$ yang mempunyai kebiasaan mencuci tangan "kadangkadang". Berdasarkan kebersihan kuku, ditemukan $65.2 \%$ responden dengan kebersihan kuku yang "kurang". Sedangkan berdasarkan kebiasaan menggunakan sendal terdapat $22.7 \%$ responden yang mempunyai kebiasaan "jarang" menggunakan alas kaki, serta $53.0 \%$ yang mempunyai kebiasaan "kadang-kadang menggunakan alas kaki ketika bermain/ ke luar rumah. Adapun 
karakteristik responden dapat dilihat pada Tabel 1 berikut.

Tabel 1 Karakteristik Responden Berdasarkan Umur, Jenis Kelamin, Tingkat Pendidikan Orang Tua dan Perilaku Hidup Bersih dan Sehat Pada Siswa SDN 1-4 Desa Murung Laung Tahun 2017

\begin{tabular}{|c|c|c|c|}
\hline No & Karakteristik & $\begin{array}{l}\text { Jumlah } \\
\text { (n) }\end{array}$ & $\begin{array}{c}\text { Persentase } \\
(\%)\end{array}$ \\
\hline 1. & $\begin{array}{ll} & \text { Umur } \\
& \\
\leq 6 & \text { tahun } \\
6-10 & \text { tahun } \\
>10 & \text { tahun }\end{array}$ & $\begin{array}{l}22 \\
26 \\
18\end{array}$ & $\begin{array}{l}33.3 \\
39.4 \\
27.3\end{array}$ \\
\hline 2. & $\begin{array}{l}\text { Jenis Kelamin } \\
\text { Laki-laki } \\
\text { Perempuan }\end{array}$ & $\begin{array}{l}36 \\
30\end{array}$ & $\begin{array}{l}54.5 \\
45.5\end{array}$ \\
\hline 3. & $\begin{array}{l}\text { Tingkat Pendidikan Orang Tua } \\
\text { SD } \\
\text { SMP } \\
\text { SMA } \\
\text { Sarjana }\end{array}$ & $\begin{array}{c}6 \\
15 \\
25 \\
20\end{array}$ & $\begin{array}{c}9.1 \\
22.7 \\
37.9 \\
30.0\end{array}$ \\
\hline 4 & $\begin{array}{l}\text { Perilaku Hidup Bersih dan Sehat } \\
\text { a. Kebiasaan Mencuci Tangan } \\
\text { - Selalu } \\
\text { - Sering } \\
\text { - Kadang-kadang } \\
\text { - Jarang } \\
\text { b. Kebersihan Kuku } \\
\text { - Ya } \\
\text { - Tdak } \\
\text { c. Kebiasaan Menggunakan Alas } \\
\text { Kaki } \\
\text { - Selalu } \\
\text { - Sering } \\
\text { - Kadang-kadang } \\
\text { - Jarang }\end{array}$ & $\begin{array}{l}7 \\
10 \\
27 \\
22 \\
\\
23 \\
43\end{array}$ & $\begin{array}{c}10.6 \\
15.2 \\
40.9 \\
33.3 \\
34.8 \\
65.2 \\
\\
15.2 \\
9.1 \\
53.0 \\
22.7\end{array}$ \\
\hline & Total & 66 & 100.00 \\
\hline
\end{tabular}

Sumber : Data Primer, 2017 
Berdasarkan hasil pemeriksaan laboratorium dengan menggunakan teknik pemeriksaan feses langsung atau metode natif, tidak ditemukan $(0.0 \%)$ adanya infeksi kecacingan pada sampel yang ditandai dengan tidak ditemukan telur dan atau larva atau cacing dewasa pada specimen tinja. Adapun gambaran infeksi kecacingan dapat dilihat pada Tabel 2 berikut

Tabel 1.2 Gambaran Infeksi Kecacingan Pada Siswa SDN 1-4 Desa Muara Laung Tahun 2017

\begin{tabular}{|c|c|c|}
\hline \multirow{2}{*}{$\begin{array}{c}\text { Infeksi } \\
\text { Kecacingan }\end{array}$} & \multicolumn{2}{|c|}{ Frekuensi } \\
\cline { 2 - 3 } & Jumlah & $\begin{array}{c}\text { Presentase } \\
(\%)\end{array}$ \\
\hline \hline Positif & 0 & 0.0 \\
\hline Negatif & 66 & 100.0 \\
\hline Total & 66 & 100.0 \\
\hline
\end{tabular}

Sumber : Data Primer, 2017 


\section{PEMBAHASAN}

Hasil penelitian menunjukan bahwa tidak ditemukan adanya infeksi kecacingan pada siswa SDN 1-4 Kabupaten Murung Raya pada Tahun 2017. Berbeda dengan hasil observasi di lapangan dimana kondisi sanitasi perumahan dan lingkungan sekolah belum memenuhi syarat kesehatan. Berdasarkan observasi sebagian besar warga belum mempunyai sanitasi lingkungan yang baik, dimana kepemilikan jamban masih rendah, sehingga sebagian besar masyarakat masih BAB di sungai. Begitupula dengan sumber air bersih, sebagian besar masyarakat menggunakan air sungai untuk melakukan aktivitas sehari-hari seperti mandi, mencuci pakaian, mencuci sayur mayur dan lain-lain.

Telur cacing golongan nematoda usus dapat keluar bersama tinja, apabila tidak ada jamban maka tinja manusia tidak terisolasi sehingga larva atau telur cacing mudah menyebar dan mengkontaminasi manusia melalui makanan atau minuman yang terkontaminasi telur cacing. Infeksi kecacingan dapat pula akibat menelan telur cacing melalui tangan yang kotor, terhirupnya telur infektif bersama debu/ udara atau kaki yang bersentuhan langsung dengan tanah melalui penetrasi larva ke kulit penderita (Soedarto,2011).

Berdasarkan hasil wawancara dan pengamatan langsung sebagian besar siswa belum menerapkan PHBS dengan baik, seperti kebiasaan mencuci tangan, menggunakan alas kaki dan menjaga kebersihan kuku. Tabel 2 menunjukan bahwa $40.3 \%$ siswa mempunyai kebiasaan "kadang-kadang" mencuci tangan sebelum makan dan setelah bermain, serta terdapat $33.3 \%$ siswa yang "jarang" mencuci tangan sebelum makan atau setelah bermain. Begitupula dengan kebiasaan menggunakan alas kaki, terdapat 22.7 \% siswa yang "jarang" menggunakan alas kaki dan $27.2 \%$ siswa yang "kadang-kadang" menggunakan alas kaki ketika bermain/ ke luar rumah. Pada aspek kebersihan kuku, ditemukan $65.2 \%$ siswa yang kebersihan kukunya kurang.

Studi epidemiologi menunjukan bahwa ada hubungan yang signifikan antara PHBS dengan kejadian infeksi kecacingan pada anak usia sekolah. Penelitian I Ketut Swirya Jaya dan Romadilah (2013), menunjukan adanya hubungan yang bermakna antara PHBS dengan kejadian infeksi kecacingan pada siswa di Kota Mataram dengan p-value 0.00 (alpha=0.05). Penularan kecacingan diantaranya melalui tangan yang kotor atau kuku yang kotor yang mungkin terselip telur cacing sehingga mengkontaminasi makanan dan minuman penderita.

Sejalan dengan penelitian Umi Mahmuda (2014) menunjukan bahwa ada hubungan ketersediaan air bersih, kepemilikian tempat sampah dan sarana pembuangan air limbah terhadap 
kejadian infeksi kecacingan di SDN Barengan Kabupaten Boyolali.

Berdasarkan pemeriksaan laboratorium ditemukan $40.21 \%$ siswa terinfeksi kecacingan akibat golongan Soil Transmitted Helmints. (Jurnal Kesehatan,

Dalam penelitian ini siswa berada dalam lingkungan yang tidak menguntungkan serta PHBS yang rendah sehingga peneliti menduga siswa berisiko terinfeksi kecacingan, namun hasil pemeriksaan laboratorium menunjukan hasil negatif pada specimen tinja yang diperiksa. Hal yang sama juga pernah diungkapkan oleh Rizka Yunidha Anwar, Nuzulia Irawati dan Machdawaty Masri (2013) dalam penelitian infeksi kecacingan pada anak SDN 25 dan 28 Parus Kota Padang, menunjukan bahwa tidak ada hubungan yang bermakna antara kebiasaan mencuci tangan, kebersihan kuku, penggunaan alas kaki dan kebiasaan mandi dengan infeksi cacing usus pada siswa SDN 25 dan 28 Purus Kota Padang Tahun 2013.

Martila, Samuel Sandi dan Nopita Paembonan (2015) dalam penelitian tentang prevalensi kecacingan pada siswa di SDN Abe Jayapura, ditemukan $50 \%$ anak terinfeksi kecacingan, dimana infeksi terbanyak disebabkan oleh Ascaris lumbricoides (48.5\%), Trichuris trichiura (28.6\%), Cacing tambang ( $14.3 \%$ ) dan infeksi campuran yang disebabkan oleh 2 (dua) atau lebih jenis cacing yaitu $28.6 \%$. Meskipun frekuensi infeksi kecacingan menunjukan angka yang signifikan, namun hasil uji statistik menunjukan bahwa tidak ada hubungan antara hygiene perorangan dengan kejadian infeksi kecacingan pada murid SD Abe Jayapura.

Berdasarkan evidence di atas, peneliti menduga bahwa tingginya infeksi kecacingan pada populasi dimungkinkan karena faktor lain seperti status gizi, sanitasi lingkungan, tingkat immunitas, pengetahuan tentang kecacingan, konsumsi obat cacing atau antibiotik dan lain-lain yang perlu diteliti lebih lanjut. Dalam penelitian ini, peneliti memperoleh informasi bahwa sebelumnya siswa telah mengkonsumsi obat cacing secara teratur yang diberikan oleh pihak sekolah bekerjasama dengan puskesmas setempat dalam rangka pengendalian kecacingan pada anak usia sekolah. Pada umumnya obat yang direkomendasikan untuk mengendalikan infeksi kecacingan adalah golongan Benzimidazole yaitu Albendazole atau Mebendazole dapat juga diberikan Levamisole atau Pyrantel Pamoatte (WHO, 2012)

Penelitian Jovita Silvia Wijaya menunjukan bahwa obat cacing sangat efektif dalam menyembuhkan infeksi kecacingan, dengan tingkat kesembuhan klinis mencapai $97.4 \%$ terutama golongan Membedazole-Pyrantel Pamoat untuk terapi infeksi Soil Tranmitted Helmints. Obat golongan Albendazole atau Mebendazole juga ektif dalam pengendalian kecacingan pada infeksi ringan karena dapat membunuh 
atau menghambat pertumbuhan cacing dalam tubuh. Lubis dkk (2013) dalam penelitian anak sekolah dasar daerah secanggang, Kabupaten Langkat Sumatera Utara mendapatkan cure rate Albendazole pada hari ke lima (93.4\%) sampai hari ke tujuh $(98.3 \%)$ untuk cacing Trichuris trichiura. Sejalan dengan penelitian Prawirakusumah, dkk (1979) pada 108 penderita dengan infestasi berbagai jenis cacing nematoda usus, tidak ditemukan telur cacing pada pemeriksaan tinja 7-10 hari setelah mengkonsumsi obat terakhir. Begitupula penelitian Deddy (2005) menunjukkan bahwa tingkat cure rate pemberian Albendazole dosis tunggal pada kasus ascariasis mencapai $100 \%$ pada minggu ketiga pengobatan.

Berdasarkan informasi, guru-guru dan orang tua di SDN 1-4 Kabupaten Murung Raya kerapkali diberi penyuluhan kesehatan tentang pencegahan kecacingan dari Puskesmas setempat, sehingga diharapkan dapat melakukan upaya-upaya pengendalian infeksi kecacingan baik di sekolah maupun di rumah. Menurut Effendi (2003), penyuluhan kesehatan merupakan salah satu cara untuk menyampaikan informasi secara efektif guna meningkatkan pengetahuan sekelompok orang yang menjadi sasaran program. Apabila informasi yang disampaikan benar-benar dapat diterima dengan baik, maka peserta dapat mengaplikasikan informasi tersebut dalam pratek sehari-hari terutama dalam pengendalian infeksi kecacingan pada anak-anak.

Penelitian Surya dan Sungkar (2013) tentang studi efektifitas penyuluhan dalam meningkatkan pengetahuan tentang kecacingan pada guru SD di Jakarta menunjukan ada perbedaan pengetahuan guru setelah mengikuti penyuluhan kesehatan. Sebelum mengikuti penyuluhan, guru yang mempunyai pengetahuan cukup adalah $17.9 \%$ dan setelah mengikuti penyuluhan, jumlah guru yang mempunyai pengetahuan cukup mengalami peningkatan hingga $58.2 \%$.

Selain dipengaruhi oleh faktorfaktor di atas, peneliti menduga bahwa hasil penelitian juga dipengaruhi oleh teknik pemeriksaan laboratorium yang digunakan. Dalam penelitian ini, metode yang digunakan adalah pemeriksaan feses langsung atau metode natif dengan melarutkan tinja dalam $\mathrm{NaCl} 0.9 \%$ kemudian specimen diamati di bawah mikroskop. Keuntungan menggunakan teknik ini adalah mudah, cepat, murah dan peralatan yang digunakan sedikit, sehingga sangat praktis apabila diterapkan di lapangan. Namun teknik ini memiliki keterbatasan yaitu tidak efektif digunakan dalam identifikasi parasit cacing terutama pada penderita dengan infeksi ringan karena tinja yang digunakan relative sedikit atau untuk memantau pengobatan anthelmintik. Oleh karena itu untuk memantau infeksi kecacingan diperlukan teknik pemeriksaan lebih 
akurat dan sensitive dibandingkan dengan metode langsung (natif) yang merupakan teknik standar yang ada saat ini. Beberapa teknik yang dapat digunakan antara lain teknik Kato-Katz, Flotasi, sedimentasi dan lain-lain.

Penelitian Barda, dkk (2013) menunjukan bahwa sensitvitas mini FLOTAC $90 \%$ dibandingkan dengan teknik kosentrasi $60 \%$ dan pemeriksaan langsung $\quad 30 \%$ dalam pemeriksaan identifikasi cacing usus. Penelitian Monica, Supali dan Wibowo (2015) ketika membandingkan uji diagnostik Mini FLOTAC dengan Kato-Katz sebelum dan sesudah pengobatan Albendazol dosis tunggal pada anak yang terinfeksi cacing usus, menunjukan bahwa teknik mini FLOTAC dapat dipakai sebagai alternantif dari teknik Kato-Katz dalam mendeteksi infeksi cacing usus dan lebih sensitive mendeteksi Trichuris trichiura dibanding Kato-Katz.

\section{KESIMPULAN}

Hasil penelitian menunjukan bahwa tidak ada siswa yang terinfeksi kecacingan di SDN 1-4 Kabupaten Murung Raya Tahun 2017 yang ditandai dengan tidak ditemukannya telur dan atau larva atau cacing dewasa pada specimen tinja yang diperiksa. Namun demikian siswa hidup dalam kondisi sanitasi lingkungan yang tidak memenuhi syarat kesehatan dan PHBS yang rendah dalam hal kebiasaan mencuci tangan maupun kebiasaan menggunakan alas kaki yang merupakan media penularan infeksi kecacingan.

Peneliti menduga bahwa hasil negatif pada pemeriksaan specimen tinja dalam penelitian ini dipengaruhi oleh 2 (dua) hal yaitu (1) Efektivitas obat cacing yang dikonsumsi siswa secara rutin ; dan (2) Keterbatasan metode yang digunakan yaitu pemeriksaan feses langsung (metode natif) yaitu tidak sensitive mengidentifikasi telur atau larva cacing pada infeksi ringan karena tinja yang digunakan relative sedikit. Oleh karena itu diperlukan penelitian lanjutan dengan menggunakan metode lain seperti KatoKatz atau Mini FLOTAC sehingga infeksi kecacingan dapat diidentifikasi sejak dini untuk menentukan program pencegahan dan pengobatan yang tepat.

\section{DAFTAR PUSTAKA}

Barda BD, Rinaldi L, lanniello D, Zepherine H, Salvo F, Sadutshang T, et al. Mini-FLOTAC, an innovative direct diagnostic technique for intestinal parasitic infections: experience from the field. Plos Negl Trop Dis. 2013; 7: 1-7

Bisara, Dina,.Mardiana.2010. Kasus Kecacingan Pada Murid Sekolah Dasar di Kecamatan Mentewe, Kabupaten Tanah Bamboo Kalimantan Selatan Tahun 2010. Jurnal Ekologi Kesehatan Vol.13 No.3. September 2014 : 255-264

Dinas Kesehatan Provinsi Kalimantan Tengah. 2014. Profil Kesehatan 
2014 Kalimantan Tengah.

Palangka Raya

Effendy, Uchjana O.2003. IImu, Teori, dan Filsafat Komunikasi. Bandung: PT. Citra Aditya Bakti.

Garcia. 1996. Diagnostik Parasitologi Kedokteran. Jakarta: Penerbit Buku Kedokteran EGC

Katzung BG.2004. Farmakologi dasar dan klinik. Medika. Bagian Farmakologi Fakultas Kedokteran Universitas Airlangga: Salemba Medika.p. 2619.

Kementrian Kesehatan RI.2016. Data dan Informasi Profil Kesehatan Indonesia. Pusat Data Dan Informasi Kementrian Kesehatan : Jakarta

Mahmuda, Umi.2014. Faktor yang Berhubungan dengan infeksi kecacingan di SDN Barengan Kabupaten Boyolali .Jurnal Kesehatan,https://doi.org/10.23917/i urkes.v10i1.5490)

Martila,.Sandi,S.Paembonan, Nopita.2015. Hubungan Hygiene Perorangan Dengan Kejadian Kecacingan Pada Murid SDN Abe Pantai Jayapura. Plasma, Vol.1, No.2, $2015: 87-96$

Monica, P, S. Supali, T,. Wibowo, Heri. 2015. Perbandingan Uji Diagnostik Mini Flotac Dengan Kato-Katz Sebelum dan Sesudah Pengobatan Albendazol Dosis Tunggal Pada Anak yang Terinfeksi Cacing Usus. Jurnal Kedokt Meditek Volume 21, No.55, Jan-April, 2015

Prawirakusumah A, Singadipoera BS, Permadhi H, Sutedja E.1979. Pemeriksaan Telur Cacing Dalam Tinja Dan Pengobatannya Dengan Trivexan. Bandung: Universitas Padjadjaran.

Putra DS, Dalimunthe W, Lubis M, Pasaribu S, Lubis C.2005. The efficacy of single-dose albendazole for the treatment of ascariasis. Paediatrica Indonesiana;45:5-6.

Rizka,I,. Nuzulia,. Machdawaty.2013. Hubungan antara Higyene Perorangan Dengan Infeksi Kecacingan Usus (Soil Transmitted Helmiths) Pada Siswa SDN 25 dan 28 Kelurahan Purus, Kota Padang, Sumatera Barat Tahun 2013. Jurnal Kesehatan Andalas, 2016; 5 (3)

Soedarto. 2011. Buku ajar Parasitologi kedokteran. Jakarta: Sagung Seto.

Supritiastuti (2006). Infeksi SoilTransmitted Helminth: Ascariasis, Trichiuriasis dan Cacing Tambang, Bagian Parasitologi FK Universitas Trisakti, Universal Medicina, Vol. 25, No. 2, April-Juni 2006 ; 84-93

Surya Dany,.Sungkar,S.2013.Efektifitas Penyuluhan Terhadap Tingkat Pengetahuan Guru SD di Jakarta Mengenai Pencegahan Kecacingan , Tahun 2011. eJKI Volume 1 No.3, desember 2013, hlm : 196-201.

Swirya,J,I,Ketut,.Romadilah.2013.

Gambaran Infeksi Kecacingan Pada Siswa SDN di Kota Mataram. Jurnal Bina Ilmiah Volume 7, No.6 Desember 2013.

Wijaya, Sillvia, Jovita.2017. Perbandingan Efektifitas dan Efek Samping Albendazole dengan Kombinasi Membendazole -Pyrantel Pamoat untuk terapi Soil Transmitted Helminthiasis Anak sekolah Dasar di Kecamatan Medan Tembung. CDK Journal-253/ Vol.44 no 6 th.2017

WHO. 2012. Research Prioritas for Helminth Infection. WHO Techn Rep Series. WHO Bull

WHO.2002. Prevention and Control of Schistosomiasis and SoilTransmitted Helminthiasis. WHO 
Nurhalina dan Desyana

Techn Rep Series Report 912. Geneva.

Yunus R. 2008. Keefektifan Albendazole Pemberian Sekali Sehari Selama 1, 2 dan 3 Hari Dalam Menanggulangi Infeksi Trichuris trichiura Pada Anak Sekolah Dasar di Kecamatan Medan Tembung [Thesis]. Medan: Universitas Sumatera Utara. 